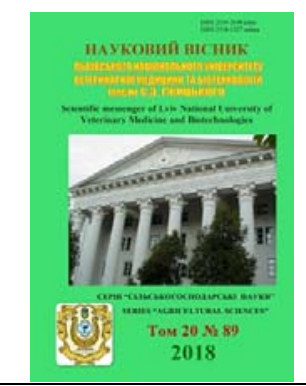

Науковий вісник Дьвівського національного університету ветеринарної медицини та біотехнологій імені С.3. Гжицького

\author{
Scientific Messenger of Lviv National University \\ of Veterinary Medicine and Biotechnologies
}

\title{
Mineral and lipid composition the body of the honeybees organism and the biological value of honey in the summer-autumn period under the conditions of feeding honey bees by citrate-capped silver and copper nanoparticles
}

\author{
I. Dvylyuk \\ Institute of Animal Biology of NAAS, Lviv, Ukraine
}

Article info

Received 17.09.2018 Received in revised form 18.10 .2018

Accepted 19.10.2018

Institute of Animal Biology of NAAS, Stusa Str., 38, Lviv, 79000, Ukraine.

Tel.: +38-050-370-74-11

E-mail:dvylyuk_ivanna@ukr.net
Dvylyuk, I. (2018). Mineral and lipid composition the body of the honeybees organism and the biological value of honey in the summer-autumn period under the conditions of feeding honey bees by citrate-capped silver and copper nanoparticles. Scientific Messenger of Lviv National University of Veterinary Medicine and Biotechnologies, 20(89), 89-94. doi: 10.32718/nvlvet8917

The article presents the results of investigations of individual mineral elements $-\mathrm{Fe}, \mathrm{Zn}, \mathrm{Cu}, \mathrm{Cr}, \mathrm{Co}$, $\mathrm{Pb}, \mathrm{Cd}$ in the tissues of the honeybees, common lipids and the ratio of their classes in the body of honey bees and the biological value of honey under the conditions of feeding of honey bees by citrate-capped silver and copper nanoparticlescitrates. The research was conducted on the honey bees of the Carpathian race on the basis of the apiary of the Stepan Gzhytskyi National University of Veterinary Medicine and Biotechnologies Lviv in the summer-autumn period in 5 groups of bee colonies, formed on the principle of analogues, by three bees colony in each group. Control group (I) received a sugar syrup in 1:1 concentration (1000 $\mathrm{ml} / \mathrm{bee} /$ week). Experimental group (II) additionally added to the syrup Ag in the amount of $0.5 \mathrm{mg} / \mathrm{l}$ of sugar syrup, the third experimental group - under similar conditions received Ag in the amount of $1 \mathrm{mg} / \mathrm{l}, \mathrm{IV}$ group received $0.5 \mathrm{mg}$ of sugar $\mathrm{Cu}$ syrup/l and $\mathrm{V}-\mathrm{Cu}$ in the amount of $1 \mathrm{mg} / \mathrm{l}$ of sugar syrup. The trace elements were injected into a sugar syrup in the form of citrates obtained by the nanotechnology method from LLC Nanomaterials and Nanotechnologies, Kyiv. Research period lasted 28 days at a feeding interval of 7 days. According to the research data, certain intergroup differences in the content of mineral elements in the bee organism have been established: the increase of $\mathrm{Fe}, \mathrm{Co}, \mathrm{Cr}$ content in the background of a probable decrease $Z n$ in the samples of the whole body tissues of the $I V$ and V experimental groups. Pb decrease in the content of the tissues of the body of all experimental groups with a high probability in the $I V$ and $V$ experimental groups $(P<0.02)$ was observed, as well as a tendency to decrease the level of $C d$ in the tissues of the whole organism in all experimental groups compared with the control group. According to the results of the conducted studies, the growth of the content of common lipids in the whole of the bees is observed and the probable differences in the fractional distribution of lipids are expressed. In particular, in the tissues of bees of all experimental group, higher levels of phospholipids and triacylglycerols were observed against the background of a decrease in the relative content of monodiacylglycerols, cholesterol. Feeding with sugar honey bees by citrate-capped silver and copper nanoparticles in the summer-autumn period was characterized by certain differences in the content of individual trace elements in honey in all experimental groups, in particular, higher content of $\mathrm{Fe}, \mathrm{Cu}$, Co in samples of honey IV and $V$ experimental groups and decrease in the concentration of $\mathrm{Cr}, \mathrm{Pb}, \mathrm{Cd}$. According to physico-chemical parameters, in honey of experimental groups, there were probably higher differences in the content of amino acids of proline, diastase activity, and a decrease in $\mathrm{pH}$, water. The content of proline in samples of honey III and IV experimental groups was higher on $22.6 \%$ and $16.9 \%(P<0.05-0.001)$ compared to control. In samples of honey II-V in experimental groups, diastase activity increased in 1.7-2.2 times $(P<0.01-0.001)$, while fluctuations of $\mathrm{pH}$ of honey by $4.0-5.0 \%(P<0.001)$ were comparatively to control. Thereby, feeding with sugar syrup citrate-capped silver and copper nanoparticles, in doses of 0.5 and $1 \mathrm{mg}$, caused a certain corrective effect on the content of $\mathrm{Fe}, \mathrm{Zn}, \mathrm{Cu}, \mathrm{Cr}, \mathrm{Co}$, and antagonistic effects on $\mathrm{Pb}, \mathrm{Cd}$ in tissues and production of honey bees.

Key words: honey bees, tissues, honey, microelements, common lipids, citrates, silver, copper, nanoparticles. 


\title{
Мінеральний і ліпідний склад тканин організму медоносних бджіл та біологічна цінність меду в літньо-осінній період за підгодівлі цитратами $\mathrm{Ag}$ i $\mathrm{Cu}$
}

\author{
I.I. Двилюк \\ Інститут біологї тварин НААН, м. Львів, Украӥна
}

У статті подано результати досліджень окремих мінеральних елементів - $\mathrm{Fe}, \mathrm{Zn}, \mathrm{Cu}, \mathrm{Cr}, \mathrm{Co}, \mathrm{Pb}, \mathrm{Cd}$ в тканинах організму медоносних бджіл, загальних ліпідів і співвідношення їхніх класів в організмі медоносних бджіл та показники біологічної иінності меду за підгодівлі цитратами Аргентуму та Купруму. Дослідження проведені на медоносних бджолах карпатської породи на базі пасіки ЛНУВМБ ім. С.3. Гжицького у літньо-осінній період на 5 групах бджолосімей, що сформовані за приниипом аналогів, по три бджолосім '̈̈ в кожній групі. Контрольна (I) група отримувала иукровий сироп 1000 мл/бджолосім'ю/тиждень. Дослідній (II) групі додатково до сиропу додавали Ag в кількості 0,5 мг/л иукрового сиропу, III дослідна група - за аналогічних умов отримувала Аg в кількості 1 мг/л, IV група отримувала з иукровим сиропом Си в кількості 0,5 мг/л і V-Cu в кількості 1 мг/л. Мікроелементи вводили до иукрового сиропу у формі иитратів, отриманих методом нанотехнології від ТОВ “Наноматеріали і нанотехнології: м. Києва. Дослідний період тривав 28 діб з інтервалом підгодівлі 7 діб. За даними досліджень встановлено певні міжгрупові різничі вмісту мінеральних елементів в організмі бджіл: зростання вмісту $\mathrm{Fe}, \mathrm{Co}, \mathrm{Cr}$ на тлі вірогідного зниження Zn у зразках тканин иілого організму IV i V дослідних груп відносно контролю. Відмічено зниження вмісту Рb у тканинах організму всіх дослідних груп $з$ вираженою вірогідністю у IV $i$ V дослідних групах $(P<0,02)$, а також зберігалася тенденція до зниження рівня Сd у тканинах цілого організму всіх дослідних груп порівняно з контрольною групою. За результатами проведених досліджень спостерігалося зростання вмісту загальних ліпідів у цілому організмі бджіл та виражені вірогідні різниці фракційного розподілу ліпідів. Зокрема, у тканинах бджіл усіх дослідних груп спостерігали вищий вміст фосфоліпідів та триацилглічеролів на тлі зниження відносного вмісту моно- $і$ диацилглцеролів, вільного холестеролу. Згодовування з иукровим сиропом цитратів Ag $i$ Си у літньо-осінній період характеризувалося певними різнииями вмісту окремих мікроелементів у меді в усіх дослідних групах, зокрема, вищий вміст $F е$, Cu, Cо у зразках меду IV i V дослідних груп та зниження конщентраџї $\mathrm{Cr}, \mathrm{Pb}, \mathrm{Cd}$. За фізико-хімічними показниками у меді дослідних груп спостерігали вірогідно вищі різниці вмісту амінокислоти проліну, діастазної активності та зниження рН, масової частки води. Вміст проліну у зразках меду III і IV дослідних груп був вищий на 22,6\% та 16,9\% (P<0,05-0,001) порівняно з контролем. У зразках меду II-V дослідних групах діастазна активність збільшувалась у 1,7-2,2 разу $(P<0,01-0,001)$, а рН меду на 4,0-5,0\% $(P<0,001)$ порівняно з контролем. Таким чином, згодовування з иукровим сиропом цитратів Ag $i$ Си в дозах 0,5 i 1 мг, спричинило певну корегуючу дію на вміст $\mathrm{Fe}, \mathrm{Zn}, \mathrm{Cu}, \mathrm{Cr}$, Со та антагоністичний вилив щодо $\mathrm{Pb}, \mathrm{Cd}$ в тканинах та продукиї̈ медоносних бджіл.

Ключові слова: медоносні бджоли, тканини, мед, мікроелементи, загальні ліпіди, цитрати, Купрум, Аргентум.

\section{Вступ}

В останні десятиріччя вивчення особливостей впливу наночастинок металів на фізіолого-біохімічні процеси в організмі тварин є надзвичайно актуальним завданням. Його вирішення відкриває нові перспективи, як у фундаментальному розумінні дії нанометалів на стан та функціональну активність організму, так і в практичному ефективному їх застосуванні (Borysevych et al., 2011; Borysevych, 2012; Nemova, 2013).

Нині особливої уваги потребує вивчення властивостей мінеральних елементів, їхнього біологічного впливу на організм тварин та накопичення у продуктах харчування, зокрема, і у продуктах бджільництва (Bogoslovskaja et al., 2009; Koval'chuk, 2014; Pashchenko et al., 2016). Мікроелементи, які містяться в організмі в незначних кількостях, володіють високою біологічною активністю (Kuz'mina, 1999). Будучи структурними компонентами ферментів, вітамінів і гормонів, вони беруть активну участь в процесах обміну речовин (Kuz'mina and Titov, 1986).

Застосування мікроелементів Аргентуму і Купруму розглядають як необхідну складову тканин тваринного організму. Висока біологічна активність цих металів пов'язана, насамперед, 3 їхньою участю в синтезі окремих ферментів, вітамінів і гормонів (Babushkina et al., 2014). Йони Ag беруть участь в обмінних процесах, залежно від концентрації вони можуть як стимулювати, так і пригнічувати активність ряду ферментів (Blagytko and Burmystrov, 2004).

Відомо, що активність Купруму в організмі тварин пов'язана із включенням до складу активних центрів окисно-відновних ферментів. Купрум є присутнім в системі антиоксидантного захисту організму як кофактору ферменту супероксиддисмутази. Важлива його роль у вуглеводневому обміні, що проявляється у прискоренні процесу окиснення глюкози і сповільненні розщеплення глікогену (Karnauhova and Shirjaeva, 2018).

Однак донині залишається нез'ясованим вплив підгодівлі бджолиних сімей цукровим сиропом із цитратами $\mathrm{Ag}$ та $\mathrm{Cu}$ на мінеральний, ліпідний склад тканин організму медоносних бджіл, біологічну цінність і якість бджолиної продукції.

Метою досліджень було дослідити вміст окремих мінеральних елементів і ліпідний склад тканин організму медоносних бджіл та якість їх продукції.

\section{Матеріал і методи досліджень}

Дослідження проведені на пасіці ЛНУВМБ iм. С.3. Гжицького на 5 групах бджолиних сімей, по три бджолосім’ї у кожній. Контрольна група (I) отримувала підгодівлю цукровим сиропом (1000 мл/ тиждень/бджолосім’ю), II дослідна група - за аналогічних умов отримувала цукровий сироп з додаванням Ag 0,5 мг у вигляді цитрату, III дослідна група - 
за аналогічних умов отримувала $\mathrm{Ag}$ у вигляді цитрату в дозах 1 мг на 1000 мл цукрового сиропу на бджолосім'ю на тиждень, a IV i V - відповідно по 0,5 і 1 мг $\mathrm{Cu}$, у вигляді цитрату на 1000 мл цукрового сиропу. Дослід проводили у літньо-осінній період (серпень вересень) тривалістю 28 діб. Мікроелементи додавали до цукрового сиропу у вигляді цитратів, що отримані від ТОВ “Наноматеріали і нанотехнологіи” м. Києва і виготовлені методом нанобіотехнології (Kosinov and Kaplunenko, 2009).

Для дослідження відбирали зразки тканин організму медоносних бджіл з бджолосімей контрольної та дослідних груп. У зразках гомогенатів тканин організму бджіл визначали вміст $\mathrm{Fe}, \mathrm{Cu}, \mathrm{Zn}, \mathrm{Co}, \mathrm{Cr}, \mathrm{Cd}$, $\mathrm{Pb}$, а також вміст загальних ліпідів за методом Фолча та співвідношення окремих фракцій ліпідів: фосфоліпідів (ФЛ), моно- і диацилгліцеролів (МДГ), вільного холестеролу (ВX), неетерифікованих жирних кислот (НЕЖК), триацилгліцеролів (ТГ), етерифікованого холестеролу (EX) - за допомогою тонкошарової хроматографії 3 використанням силікагелевих пластин Sorbfil (ПТСХ-П-А) з подальшим вимірюван- ням показників оптичної густини у дослідних зразках тканин на спектрофотометрі СФ-46 при довжині хвилі 440 нм (Folch et al., 1957). Вміст мінеральних елементів визначали атомно-абсорбційним методом на СФ-115 ПК (Vlizlo et al., 2012). Якісні показники згідно із загальноприйнятими методиками (Med naturalnyi, 2005)

Одержані числові дані опрацьовані за допомогою стандартного пакету статистичних програм Microsoft EXCEL 7.

\section{Результати та їх обговорення}

Потреба бджіл у макро- і мікроелементах забезпечується їхнім надходженням з пилком рослин, водою і нектаром. За даними літератури, додавання до корму бджіл сполук окремих мікроелементів як метаболічних стимуляторів органічного та неорганічного походження, внесених у різних дозах, впливає на корекцію фізіолого-біохімічних процесів і підвищує продуктивність медоносних бджіл (Shagun, 1982; Shagun, 1987; Romaniv, 2012, Fedoruk et al., 2014).

\section{Таблиця 1}

Вміст мінеральних елементів в тканинах організму медоносних бджіл, мг/кг натуральної маси $(\mathrm{M} \pm \mathrm{m}, \mathrm{n}=3)$

\begin{tabular}{crrrrc}
\hline \multirow{2}{*}{ Мінеральні елементи } & \multicolumn{5}{c}{ Групи медоносних бджіл } \\
\cline { 2 - 6 } & \multicolumn{1}{c}{$\mathrm{I}$} & \multicolumn{1}{c}{ II } & \multicolumn{1}{c}{ IV } & $\mathrm{V}$ \\
\hline $\mathrm{Fe}$ & $28,27 \pm 1,55$ & $29,47 \pm 1,69$ & $29,63 \pm 1,14$ & $26,87 \pm 1,10$ & $27,67 \pm 1,33$ \\
$\mathrm{Cu}$ & $6,85 \pm 0,40$ & $6,64 \pm 0,25$ & $6,70 \pm 0,26$ & $7,50 \pm 0,33$ & $8,35 \pm 0,25^{*}$ \\
$\mathrm{Zn}$ & $31,00 \pm 1,14$ & $32,11 \pm 0,79$ & $32,41 \pm 1,81$ & $26,24 \pm 1,0^{*}$ & $25,33 \pm 1,43^{*}$ \\
$\mathrm{Cr}$ & $2,22 \pm 1,14$ & $2,06 \pm 0,08$ & $2,16 \pm 0,17$ & $2,36 \pm 0,03$ & $2,44 \pm 0,06$ \\
$\mathrm{Co}$ & $1,21 \pm 0,11$ & $1,27 \pm 0,06$ & $1,25 \pm 0,05$ & $1,34 \pm 0,25$ & $1,40 \pm 0,13$ \\
$\mathrm{~Pb}$ & $1,82 \pm 0,15$ & $1,76 \pm 0,08$ & $1,56 \pm 0,09$ & $1,22 \pm 0,06^{*}$ & $1,11 \pm 0,05^{*}$ \\
$\mathrm{Cd}$ & $0,24 \pm 0,04$ & $0,21 \pm 0,02$ & $0,18 \pm 0,008$ & $0,20 \pm 0,01$ & $0,17 \pm 0,008$ \\
\hline
\end{tabular}

Примітка: у цій і наступних таблицях *-P $<0,05-0,02, * *-\mathrm{P}<0,01, * * *-\mathrm{P}<0,001$

За результатами досліджень встановлено зниження вмісту Феруму в гомогенаті тканин медоносних бджіл IV - на 5,0\% i V - 2,1\% дослідних груп на тлі вищого вмісту рівня Купруму на $9,5 \%$ та $21,9 \%(\mathrm{P}<0,05)$ відповідно. Вміст Цинку характеризувався вищим вмістом у зразках тканин організму II і III дослідних груп на тлі вірогідно нижчого рівня цього елементу у IV i V групі ( $<$ 0,05). Суттєвих міжгрупових різниць вмісту Cr i Co у тканинах медоносних бджіл у всіх досліджуваних групах порівняно 3 контролем не спостерігалося. Варто відзначити певний антагоністичний вплив Аргентуму i Купруму у наноцитратній формі на концентрацію більш токсичних металів, зокрема Свинцю і Кадмію. Вміст Рb знижувався у тканинах II і III дослідних груп у 1,1-1,3 раза, a IV i V - в 1,2 і 1,4 (P < 0,05) разу відповідно. Тенденцію до зниження спостерігали для вмісту $\mathrm{Cd}$ у тканинах цілого організму бджіл II-V дослідних груп у 1,11,4 разу порівняно з контролем.

Ліпіди в організмі медоносних бджіл є основним резервним компонентом, що депонується в тканинах жирового тіла і активно використовується в процесі метаморфоз (Kovalska et al., 2009). Жирове тіло являє собою важливий орган обміну речовин і $\epsilon$ визначальним у якості та активності перебігу фізіолого- біохімічних процесів в організмі медоносних бджіл. Саме тому ступінь розвитку жирового тіла є основним показником біологічного стану організму медоносних бджіл та впливає на тривалість їхнього життя (Larionova, 2005). Регуляція ліпідного та вуглеводного обміну в осінній період має важливе фізіологічне значення, оскільки літні бджоли відрізняються від осінніх як збільшенням маси, так і тривалістю життя (Yang et al., 2017). Це пов'язано із збільшенням маси таких внутрішніх органів, як глоткові залози і жирове тіло (Kovalskyi et al., 2017). В організмі бджіл у осінній період активно накопичуються резервні ліпіди, глікоген, а також протеїни, що необхідні для забезпечення енергетичних і пластичних процесів в цей період.

Аналіз результатів досліджень свідчить про зміни вмісту загальних ліпідів у тканинах цілого організму медоносних бджіл дослідних груп порівняно $з$ контролем у період згодовування 3 цукровим сиропом цитратів $\mathrm{Ag}$ i $\mathrm{Cu}$ (табл. 2). Зокрема, встановлено вищий вміст загальних ліпідів у тканинах медоносних бджіл усіх дослідних груп, що свідчить про однаковий стимулюючий вплив застосованих концентрацій добавок на обмін ліпідів і їхній синтез у тканинах медоносних бджіл. 
У тканинах медоносних бджіл дослідних груп спостерігали вищий вміст фосфоліпідів та триацилгліцеролів ( $<<0,05)$, що, очевидно, зумовлено стимулюючою дією добавки цитратів на обмін фосфоліпідів в організмі бджіл цих груп. Встановлено нижчий вміст вільного холестеролу ( $<<0,05-0,01)$ та НЕЖК у тканинах бджіл дослідних груп порівняно з контролем.
Біологічна цінність меду характеризується вмістом окремих біологічно активних речовин, таких як ферменти, органічні кислоти, вітаміни, ароматичні й азотисті сполуки, мінеральні елементи, що надходять 3 пилком і нектаром медоносних рослин, а також із секретом травних залоз бджіл.

\section{Таблиця 2}

Вміст загальних ліпідів та окремих фракцій в організмі медоносних бджіл, \% $(\mathrm{M} \pm \mathrm{m}, \mathrm{n}=3)$

\begin{tabular}{lrrrrr}
\hline \multirow{2}{*}{ Класи ліпідів } & \multicolumn{5}{c}{ Групи бджіл } \\
\cline { 2 - 6 } & \multicolumn{1}{c}{ І к } & \multicolumn{1}{c}{ II } & III & IV & V \\
\hline Загальні ліпіди, г\% & $3,50 \pm 0,06$ & $3,68 \pm 0,09$ & $3,60 \pm 0,06$ & $3,76 \pm 0,12$ & $3,80 \pm 0,06$ \\
ФЛ & $20,68 \pm 0,69$ & $20,78 \pm 1,0$ & $22,21 \pm 0,93$ & $22,91 \pm 0,21$ & $21,86 \pm 0,14$ \\
МДГ & $14,67 \pm 0,12$ & $15,00 \pm 0,49$ & $12,84 \pm 0,39^{*}$ & $14,41 \pm 0,59$ & $13,78 \pm 0,48$ \\
ВХ & $14,85 \pm 0,32$ & $13,57 \pm 0,68$ & $12,99 \pm 0,24^{* *}$ & $12,97 \pm 0,54^{*}$ & $12,92 \pm 0,25^{* *}$ \\
НЕЖК & $17,89 \pm 0,35$ & $16,20 \pm 0,68$ & $18,36 \pm 0,07$ & $16,16 \pm 0,34$ & $16,32 \pm 0,73$ \\
ТГ & $17,51 \pm 0,77$ & $19,15 \pm 0,33$ & $18,54 \pm 0,33$ & $19,18 \pm 0,92$ & $20,37 \pm 0,27^{*}$ \\
ЕХ & $14,41 \pm 0,62$ & $15,29 \pm 0,56$ & $15,05 \pm 0,16$ & $14,37 \pm 0,08$ & $14,57 \pm 0,57$ \\
\hline
\end{tabular}

Таблиця 3

Вміст окремих мікроелементів в поліфлорному меді, мг/кг натуральної маси $(\mathrm{M} \pm \mathrm{m}, \mathrm{n}=3)$

\begin{tabular}{ccccc}
\hline \multirow{2}{*}{ Мікроелементи } & \multicolumn{4}{c}{ Групи медоносних бджіл } \\
\cline { 2 - 5 } & $\mathrm{I}$ & $\mathrm{II}$ & $\mathrm{III}$ & $\mathrm{IV}$ \\
$\mathrm{Fe}$ & $4,92 \pm 0,38$ & $4,16 \pm 0,06$ & $4,42 \pm 0,43$ & $5,68 \pm 0,28$ \\
$\mathrm{Cu}$ & $1,96 \pm 0,09$ & $1,89 \pm 0,09$ & $1,81 \pm 0,06$ & $2,16 \pm 0,12$ \\
$\mathrm{Zn}$ & $0,87 \pm 0,12$ & $0,92 \pm 0,91$ & $1,11 \pm 0,09$ & $0,63 \pm 0,03$ \\
$\mathrm{Co}$ & $0,32 \pm 0,04$ & $0,35 \pm 0,05$ & $0,33 \pm 0,03$ & $0,41 \pm 0,03$ \\
$\mathrm{Cr}$ & $0,52 \pm 0,04$ & $0,48 \pm 0,04$ & $0,45 \pm 0,04$ & $0,44 \pm 0,03$ \\
$\mathrm{~Pb}$ & $0,55 \pm 0,04$ & $0,45 \pm 0,04$ & $0,53 \pm 0,06$ & $0,47 \pm 0,02$ \\
$\mathrm{Cd}$ & $0,10 \pm 0,01$ & $0,06 \pm 0,01$ & $0,08 \pm 0,02$ & $0,03 \pm 0,09$ \\
& & & $0,43 \pm 0,04 \pm 0,01 *$ & $0,05 \pm 0,01 *$ \\
\hline
\end{tabular}

За результатами досліджень згодовування з цукровим сиропом цитратів Аргентуму і Купруму у літньоосінній період зумовило певні різниці вмісту окремих мікроелементів у продукції бджіл, зокрема у меді в усіх дослідних групах. Встановлено вищий вміст Феруму, Купруму, Кобальту у зразках меду IV i V дослідних груп на фоні зниження у II і III дослідних групах. Так, концентрація Fe у меді IVдослідної групи зросла на $15,4 \%, \mathrm{~V}$ - на 23,4\% відносно контролю, а вміст $\mathrm{Cu}$ у меді - на $10,2 \%, \mathrm{~V}$ - на $13,26 \%$ відповідно. У зразках меду бджіл дослідних груп відзначено вищий вміст Zn (крім III групи), Со на тлі зниження $\mathrm{Cr}$ порівняно 3 контролем. Варто відзначити нижчі концентрації $\mathrm{Pb}$ та $\mathrm{Cd}$ - у 1,6 раза - II та у 1,25 раза III, 2,5 раза - IV $(\mathrm{P}<0,05), 2,0$ раза $-\mathrm{V}$ дослідних групах $(\mathrm{P}<0,05)$ порівняно з контролем.

Підгодівля бджіл цукровим сиропом 3 додаванням цитратів $\mathrm{Ag}$ і $\mathrm{Cu}$ зумовлювала вірогідні зміни фізикохімічних показників меду дослідних груп. Зокрема, у зразках меду II-V дослідних груп діастазна активність збільшувалась у $1,5-2,2$ разу $(\mathrm{P}<0,01-0,001)$ відповідно.

\section{Таблиця 4}

Фізико-хімічні показники меду за умов згодовування наноаквацитратів $\mathrm{Ag} \mathrm{i} \mathrm{Cu} \mathrm{(M \pm m,} \mathrm{n} \mathrm{=} \mathrm{3)}$

\begin{tabular}{lccccc}
\hline \multirow{2}{*}{ Показники } & \multicolumn{5}{c}{ Групи медоносних бджіл } \\
\cline { 2 - 6 } & $\mathrm{I}$ & $\mathrm{II}$ & $\mathrm{III}$ & $\mathrm{IV}$ & $\mathrm{V}$ \\
\hline Пролін & $226,98 \pm 2,1$ & $258,7 \pm 5,8^{* *}$ & $278,3 \pm 9,5^{* *}$ & $265,2 \pm 11,5^{*}$ & $243,5 \pm 4,3^{*}$ \\
Діастазне число, од. Готе & $7,86 \pm 0,07$ & $13,23 \pm 1,1^{* *}$ & $12,27 \pm 0,6^{* * *}$ & $17,3 \pm 0,3^{* * *}$ & $11,9 \pm 0,4^{* * *}$ \\
$\mathrm{pH}$ & $4,24 \pm 0,006$ & $4,07 \pm 0,01^{* * *}$ & $4,08 \pm 0,01^{* * *}$ & $4,06 \pm 0,01^{* * *}$ & $4,0 \pm 0,03^{* * *}$ \\
Масова частка води & $18,33 \pm 0,1$ & $18,07 \pm 0,1$ & $17,67 \pm 0,06^{* *}$ & $18,53 \pm 0,06$ & $18,30 \pm 0,1$ \\
\hline
\end{tabular}

До біологічно активних речовин у меді відносять пролін (піролідин- $\alpha$-карбонова кислота). Це - гетероциклічна амінокислота, що входить до складу всіх білків живих організмів. Пролін поряд з іншими амінокислотами входить до складу меду. Вміст його значно перевищує вміст інших амінокислот і коливається в межах від 170 до 770 мг/кг. Масова частка проліну є важливим критерієм якості меду. Кількість проліну є показником зрілості і фальсифікації меду. За результатами досліджень вміст проліну в меді був вищим у III i IV дослідних групах на $22,6 \%$ та $16,9 \%$ ( $<<0,05-0,001)$ відповідно. За рахунок цього підвищується кислотність меду його стабільність щодо зберігання, а також стійкість до бродіння. Коливання 
показника $\mathrm{pH}$ меду в усіх досліджуваних зразках характеризувалося нижчим рівнем у II-V дослідних групах на 4,0-5,0\% (P < 0,001).

Як відомо, бджоли в процесі переробки нектару фільтрують і зменшують вміст вологи, внаслідок чого змінюється густина, консистенція і швидкість кристалізації, що впливає на термін зберігання і якість меду. У меді бджіл, яким згодовували 3 цукровим сиропом цитрат Ag масова частка води була нижчою в II та III дослідних групах $(\mathrm{P}<0,01)$ порівняно з контролем.

Отже, підгодівля бджіл цукровим сиропом 3 цитратами $\mathrm{Ag}$ і $\mathrm{Cu}$ стимулює синтез та збагачення меду проліном, зростання діастазного числа, що вказує на доцільність застосування цих добавок у підгодівлі бджіл в літньо-осінній період для підвищення біологічної цінності меду.

\section{Висновки}

1. Додаткове згодовування бджолам з сиропом Аргентуму та Купруму у вигляді цитрату зумовлювало міжгрупові різниці вмісту окремих мінеральних елементів, загальних ліпідів і вірогідно виражені зміни співвідношення їхніх класів у тканинах організму i продукції медоносних бджіл.

2. Підвищення мінерального і ліпідного живлення медоносних бджіл 3 підгодівлею у літньо-осінній період цитратів $\mathrm{Ag}$ i $\mathrm{Cu}(0,5$ i 1 мг/1000 мл цукрового сиропу) зумовлює фізіологічно нижчий вміст вільного холестеролу, НЕЖК, монодиацилгліцеролів, Fe, Zn, $\mathrm{Pb}, \mathrm{Cd}$ i зростання рівня фосфоліпідів, триацилгліцеролів і загальних ліпідів, $\mathrm{Cu}, \mathrm{Cr}, \mathrm{Co}$ у тканинах організму медоносних бджіл, а також $\mathrm{Fe}$, $\mathrm{Cu}, \mathrm{Co}$, рівня проліну та діастазної активності у меді.

\section{References}

Babushkina, I.V., Gladkova, E.V., Mamonova, I.A., Norkin, I.A., \& Puchin'jan, D.M. (2014). Biologicheskaja aktivnost' nanochastic medi v eksperimente. Fundamental'nye issledovanija, 6, 1204-1207. https://elibrary.ru/item.asp?id=21618787 (in Russian).

Blagytko, E.M., \& Burmystrov, V.A. (2004). Silver in medicine. Novosibirsk, Nauka-Centr Publ. (in Russian).

Bogoslovskaja, O.A., Sizova, E.A., Poljakova, V.S., Miroshnikov, S.A., Lejpunskij, I.O., Ol'hovskaja, I.P., \& Glushhenko, N.N. (2009). Izuchenie bezopasnosti vvedenija nanochastic medi s razlichnymi fizikohimicheskimi harakteristikami $\mathrm{v}$ organizm zhivotnyh. Vestnik Orenburgskogo gosu-darstvennogo universiteta, 2, 124-127. http://vestnik.osu.ru/2009_2/21.pdf (in Russian).

Borysevych, V.B. (2012). Nanomaterialy i nanotehnologii v veterinarnoj praktike. K.: Avicena (in Ukrainian).

Borysevych, V.B., Kaplunenko, V.H., \& Kosinov, M.V. (2011). Zdobutky i problemy nanotekhnolohii u veterynarnii praktytsi. Zdorovia produktyvnykh tvaryn, 10, 30-31. https://lib.dsau.dp.ua/book/83160 (in Ukrainian).
Fedoruk, R.S., Kovalchuk, I.I., Romaniv, L.I., \& Khrabko, M.I. (2014). Vplyv tsytrativ Ge ta Se na vmist lipidiv i vazhkykh metaliv $\mathrm{v}$ orhanizmi medonosnykh bdzhil. Biolohiia tvaryn, 14(2), 141-149. http:/oaji.net/articles/2017/2722-1504274089.pdf （in Ukrainian).

Folch, J., Lees, M., \& Sloane-Stanley, G.H. (1957). A simple method for the isolation and urification of total lipids from animal tissues. J. Biol. Chem., 226, 497500. https://www.ncbi.nlm.nih.gov/pubmed/13428781.

Karnauhova, I.V., \& Shirjaeva, O.Ju. (2018). Issledovanie soderzhanija medi i aktivnosti med'-zavisimoj superoksiddismutazy v organizme cheloveka. Nauchnoe obozrenie. Biologicheskie nauki, 2, 10-14. https://science-biology.ru/ru/article/view?id=1096 (in Russian).

Kosinov, M.V., \& Kaplunenko, V.H. (2009). Patent Ukrainy na korysnu model № 39392. Sposib otrymannia karboksylativ kharchovykh kyslot $\mathrm{Z}$ vykorystanniam nanotekhnolohii. MPK (2009): SO7S 51/41, SO7F 5/00, SO7F 15/00, V82V 3/00. Opubl. 25.02.2009, biul. № 4/2009 (in Ukrainian).

Koval'chuk, I.I. (2014). Soderzhanie tjazhelyh metallov v tkanjah organizma pchel pri skarmlivanii citrata germanija. Mikrojelementy $\mathrm{v}$ medicine, 15(3), 42-47. https://elibrary.ru/item.asp?id=22255716 (in Ukrainian).

Kovalska, L.M., Kyryliv, Ya.I., \& Kovalskyi, Yu.V. (2009). Lipidnyi sklad okremykh tkanyn medonosnykh bdzhil u vikovomu aspekti. Naukovo-tekhnichnyi biuleten Instytutu biolohii tvaryn i Derzhavnoho naukovo-doslidnoho kontrolnoho instytutu vetpreparativ ta kormovykh dobavok, 10(1-2), 51-56. http://archive.inenbiol.com.ua:8080/ntb/ntb3/pdf/1/9.pd $\mathrm{f}$ (in Ukrainian).

Kovalskyi, Yu.V., Kovalska, L.M., \& Myronovych, H.M. (2017). Osoblyvosti obminu lipidiv V orhanizmi medonosnykh bdzhil (Apis mellifera 1.) za vplyvu hipotermichnoho stresu. Bdzhilnytstvo Ukrainy, 2, 129-139. http://nbuv.gov.ua/UJRN/bdjukr_2017_2_17 (in Ukrainian).

Kuz'mina, Je.V. (1999). Soderzhanie mineral'nyh veshhestv v organizme i v otdel'nyh organah medonosnyh pchel. Sb. nauchn. tr. Problemy jentomologii i arahnologii. Tjumen', 80-82 (in Russian).

Kuz'mina, Je.V., \& Titov, V.F. (1986). Vlijanie mineral'nyh podkormok na razvitie pchelinyh semej. Nauchno-tehnicheskij bjull. VNII vet. jentomologii i arahnologii. Tjumen', 3, 3-8 (in Russian).

Larionova, O.S. (2005). Dinamika soderzhanija zhira v organizme rabochih pchel $\mathrm{v}$ uslovijah estestvennoj sredy pri razlichnyh vidah podkormok i masse otvodkov. Sovremennye problemy intensifikacii proizvodstva v APK: tr. Vseros. NII kontrolja standartizacii i sertifikacii veterinarnyh preparatov, 88-89 (in Russian).

Med naturalnyi (2005). Tekhnichni umovy: DSTU 4497:2005 [Chynnyi vid 28 hrudnia 2005 r.]. K.: Derzhspozhyvstandart Ukrainy, 21 (in Ukrainian).

Nemova, T.V. (2013). Perspektyvy zastosuvannia preparativ na osnovi nanotekhnolohii $u$ veterynarnii 
medytsyni. Veterynarna medytsyna Ukrainy. 1, 35-37 (in Ukrainian).

Pashchenko, A.H., Fedoruk, R.S., Romaniv, L.I., \& Kovalchuk, I.I. (2016). Umist mikroelementiv u tkanynakh medonosnykh bdzhil za zghodovuvannia tsukrovoho syropu, boroshna soi i tsytrativ So ta Ni. Naukovyi visnyk LNUVMB, 18, 2(67), 168-172. doi: 10.15421/nvlvet6738 (in Ukrainian).

Romaniv, L.I. (2012). Lipidnyi sklad tkanyn hrudei i cherevtsia medonosnykh bdzhil za zghodovuvannia dobavky khlorydu ta tsytratu khromu. Naukovyi Visnyk LNUVMB im. S.Z. Hzhytskoho, 14, 3(3), 170-175. http://nbuv.gov.ua/UJRN/nvlnu_2012_14_3\%283\%29 34 (in Ukrainian).

Romaniv, L.I., Kovalchuk, I.I., Pashchenko, A.G., \& Fedoruk, R.S. (2018). Content of lipids in tissues of the melliferous bees additional fed with soybean meal, sugar syrup and citrates of Co and Ni. Bìol. Tvaryn, 20(3), 84-92. doi: 10.15407/animbiol20.03.084.

Shagun, L.A. (1982). Mineral'nye podkormki i fiziologicheskoe sostojanie pchel. Pchelovodstvo, 8, 15-16 (in Russian).

Shagun, L.A. (1987). Podkormka s mineral'nymi dobavkami. Pchelovodstvo, 1, 11 (in Russian).

Vlizlo, V.V., Fedoruk, R.S., \& Ratych, I.B. (2012). Laboratorni metody doslidzhen u biolohii tvarynnytstvi ta veterynarnii medytsyni. Dovidnyk. Lviv (in Ukrainian).

Yang, W., Tian, Y., Han, M., \& Miao, X. (2017). Longevity extension of worker honey bees (Apis mellifera) by royal jelly: optimal dose and active ingredient. PeerJ., 28, 5:e3118. doi: 10.7717/peerj.3118. 